\title{
A Virtual Room to Enhance Writing Skills in the EFL Class
}

\author{
Uso del aula virtual para mejorar las habilidades \\ de escritura en inglés como lengua extranjera ${ }^{*}$
}

\section{Dayra Piedad Ochoa Alpala}

dayrapiedad8a@hotmail.com

Universidad de Boyacá, Colombia

Nieves Medina Peña

seveinmp@hotmail.com

Universidad Pedagógica y Tecnológica de Colombia

This article reports an action research that intended to study to what extent students shape their writing skill in English through the use of a virtual room. As the study, we randomly selected six ninth graders in high school from thirty two students at a Colombian private institution. Three instruments were used, namely, interviews, students' artifacts, and journals. The results indicate that the use of virtual resources enriches students' learning process and engages them to communicate and interact with their classmates through their written creations.

Key words: English as a foreign language, technology, virtual room, writing skill

En este artículo se presenta una investigación acción cuyo propósito es estudiar en qué medida los estudiantes forman su habilidad escritural en inglés a través del aula virtual. Como grupo de estudio, se seleccionaron al azar seis estudiantes de un total de treinta y dos en una institución privada colombiana. Se emplearon tres instrumentos de recolección de datos: entrevistas, producciones de los estudiantes y diarios. Los resultados indican que el uso de recursos virtuales enriquece el aprendizaje de los estudiantes y los motiva a comunicarse e interactuar con sus compañeros a través de sus producciones escritas.

Palabras clave: aula virtual, inglés como lengua extranjera, habilidad escritural, tecnología

Received: September 2, 2013. Accepted: February 7, 2014. 


\section{Introduction}

Education has been widely influenced by deep changes in relation to science and technology. Teachers have felt the need to incorporate new information and communication technologies (web pages, chats, blogs, wikis, etc.) into the teaching-learning process, modifying the way the educational system works. Klopfer, Osterweil, Groff, and Haas (2009) state: "Technologies afford us the ability to convey concepts in new ways that would otherwise not be possible, efficient or effective, with other instructional methods" (p. 4). These changes are evident in the implementation of new resources into the classroom: computers, tape recorders, video recorders, video beams, among others. Thus, some teachers have left aside the use of the board as the only resource for teaching. Klopfer et al. argue that "The emergence of new technologies pushes the educator to understanding and leveraging these technologies for classroom use" (p. 10).

One of the innovative technologies teachers are using in their classes refers to virtual rooms that offer a cooperative and communicative learning space in which participants can interact among themselves by using the computer and resources in a simulated environment. Virtual tools (chat, wikis, web pages) constitute an important aspect of teenagers' daily lives, since they often use technology for different purposes (homework, entertainment, communication). Pfister, Schuckmann, Beck-Wilson, \& Wessner (1998) state that "virtual rooms provide a natural analogue to real life learning situations. Hence, learners have a background knowledge for orientation and behavior in the learning environment" (p. 112).

Regarding the issues mentioned above, we researched the use of virtual tools in a private school and noticed that in the English classes students do not have contact with technological resources and their writing is only focused on the structure of the language. For instance, students have to build sentences for each verbal tense without having a purpose or a concern about the uses of such grammatical forms, as shown in the sample text below where students were asked to write five sentences in past simple.

I saw a dog in street.

She found a wallet in cinema.

They made the homework of English yesterday.

We drank beer in bar.

Rosa played in the park. [sic]

Based on this information, we as teachers and researchers began to explore the virtual context to carry out authentic communicative activities, so the following research question emerged:

To what extent does the use of a virtual room shape the EFL writing of students in a private school? 


\section{Literature Review}

\section{Virtual Room}

Hiltz (1987) defines a virtual room as "an interactive communication and learning space located within a computer system used to create an electronic analogue of the communication forms that usually occur in a classroom" (p. 265). In relation to this definition, a virtual room becomes a space in which learners can engage in language use for communicative purposes by interacting with the others through a variety of virtual tools that constitute a powerful complement for learning situations of the classroom. In addition, this virtual space presents a combination of image, video, sound, and text, where students can interact and use these elements simultaneously. In this respect, Tiffin and Rajasingham (1995) assert that in the virtual classroom students can access and develop a set of actions that characterize a conventional teaching and learning process involving conversations, document reading, asking the teacher questions, group work, and so on. All of these actions are carried out in a simulated way, so physical interaction between teachers and students is not required.

Additionally, the characteristics of virtual rooms imply the use of some e-platforms, such as blackboard, learning platform, web CT, among others, and in our case, we worked with a Modular Object-Oriented Dynamic Learning Environment (MOODLE) platform. According to Dougiamas (1998) such platform is based on socio-constructivism pedagogy. This type of pedagogy consists of three general concepts: constructivism (Williams \& Burden, 1997), constructionism (Papert \& Harel, 1991), and social constructivism (Bruffee, 1986).

Through virtual rooms, learners can share information using a wide variety of texts and graphic media, including voice and video and build learning communities and work teams by means of virtual connections, even though people may never physically meet. Students can also interact with and learn from fellow classmates, exchange ideas, meet with small teams, and present or participate in training classes.

\section{Virtual Room in EFL Learning}

A virtual room constitutes a complement for EFL learning, since it provides students with a variety of resources (video, image, text, and sound) to practice grammar aspects, reinforce the topics worked in class, and use the language with communicative purposes. Moreover, a virtual room involves students' cooperative work to accomplish virtual activities related to simulated environments. They have also the opportunities to share experiences, points of view, and knowledge by interacting virtually among themselves and the teacher.

In this regard, Rojas (2011) carried out a study about the use of blogs to engage Colombian adolescents in meaningful communication in a public school. The research 
project took into account the implementation of a specific blog that proposes activities, suggestions, strategies, and links to increase written communication in English. She found that students were encouraged to write and communicate among themselves and concluded that blogs and other virtual tools are excellent to work with students in a creative and interesting way.

\section{Writing Skill}

Byrne (1988) states that "writing refers to the production of graphic symbols which have to be arranged, according to certain conventions to form words, and words have to be arranged to form sentences" (p. 98). That is why writing constitutes a whole process of connecting specific elements to build a complete text, which needs to have some cohesion and coherence requirements in order to communicate related ideas that lead to a global sense.

Types of writing. There are different types of writing and Wassman and Rinsky (1997) separate them into categories like persuasion, in which the author attempts to convince a person of something to think as he/she does; description, which is the most helpful in creating a picture of something concrete such as a scene or a person; exposition, in which the author expounds upon information or ideas, gives information, explains something, clarifies a process, or defines a concept. This kind of writing is objective and not dependent on emotion; and finally, narration, in which the writer relates events in sequence. This type of writing recounts a personal experience or tells a story based on a real or imagined event with all the details getting integrated in order to create some central themes or impressions and, in the case of fiction, it is created to entertain the reader. The last two types are the ones promoted by the various activities which are implemented in the pedagogical strategy of this project.

In regard to the aspects mentioned above, Freed, Burton, and Kelly (as cited in Scott, 1996) carried out a study involving native speakers of English. It indicated that writers have different levels of ability in different language models. Using topics requiring narration, description, and persuasion, college students representing basic, average, and honors writers participated in the research. The researchers found that descriptive writing was a difficult task for basic writers, an intermediately difficult discourse for average writers, and an easy task for honors writers. On the other hand, for basic writers persuasive writing was the most difficult discourse, and it was placed close to intermediately difficult for average and honors writers.

The previous research evidences the fact that writers may have competence in some of the types of writing but not necessarily in all of them, and also the role of the writing discourse in writing competence. Scott (1996) states that writing competence refers to one of the dimensions, which comprises the overall term communicative competence. In addition, Krashen (as cited in Scott, 1996) defines writing competence as "the abstract knowledge the proficient writer has about writing" (p. 165); it also implies his own perspective and the specific strategies 
used by him/her while writing. In the next section the type of research, setting, population, participants as well as instruments and techniques used to collect data will be described.

\section{Research Design}

This project was based on a qualitative paradigm or philosophy which aims to understand facts by explaining and interpreting results of studies. According to Sandin (2003), qualitative research is "a systematic activity guided to the comprehension of educational phenomenon and the transformation of the socio-educational sceneries" (p. 123). Thus, the project analyzes and draws conclusions about the implications of using virtual resources to foster students' writing skill.

Following the principles of qualitative paradigm, the study used an action research methodology, since it is concerned with diagnosing a problem in a specific context, in this case, students' difficulties when writing texts in English, and attempting to solve it in that context. In regard to this type of research, Parsons and Brown (2002) state: "Action research is a form of investigation designed for use by teachers to attempt to solve problems and improve professional practices in their own classrooms" (p. 32). From Calhoun's (1994) perspective: “Action research is a fancy way of saying let's study what's happening at our school and decide how to make it a better place" (p. 16). So, this type of research seeks to create knowledge, propose and implement change, and improve practice and performance.

\section{Participants}

The participants to work with in the implementation of the pedagogical strategy were six ninth grade students. Of this population, three were female and three were male. Their age range was from 13 to 15 years old. These students were chosen at random to be the study group. However, from the beginning to the end, the project was carried out with the whole group of ninth graders.

\section{Method}

During the implementation of the proposal, students worked once a week for four months carrying out eleven workshops focused mostly on texts writing. Each workshop had activities arranged in coherent sequences to reach different writing aims. Thus, in each session they had to develop online exercises and use virtual resources to be engaged in the different topics and, as the last step, they had to create a text to show their understanding of the whole unit. Students did not use notebooks and papers. Table 1 shows the name of the workshops, the topics dealt with in each one, and the objectives to reach. 
Table 1. Summary of Workshops

\begin{tabular}{|c|c|c|}
\hline Heading & Topics/Skills & Objective \\
\hline $\begin{array}{l}\text { 1. My last vacation } \\
\text { Time: } 2 \text { hours }\end{array}$ & $\begin{array}{l}\text { Simple past tense; } \\
\text { structure and uses. }\end{array}$ & $\begin{array}{l}\text { To talk about past activities through } \\
\text { chat interaction. }\end{array}$ \\
\hline $\begin{array}{l}\text { 2. What did you do yesterday? } \\
\text { Time: } 2 \text { hours }\end{array}$ & $\begin{array}{l}\text { Simple past tense; } \\
\text { structure and uses. }\end{array}$ & $\begin{array}{l}\text { Using the wiki as a tool for creating } \\
\text { virtual comics and writing. }\end{array}$ \\
\hline $\begin{array}{l}\text { 3. Expressing personal opinions } \\
\text { Time: } 2 \text { hours }\end{array}$ & $\begin{array}{l}\text { Present simple; } \\
\text { structure and uses. }\end{array}$ & $\begin{array}{l}\text { To express opinions in relation to } \\
\text { drugs consumption through the } \\
\text { forum as a virtual tool. }\end{array}$ \\
\hline $\begin{array}{l}\text { 4. Likes and dislikes } \\
\text { Time: } 2 \text { hours }\end{array}$ & Yes/No questions. & $\begin{array}{l}\text { To talk about likes and dislikes using } \\
\text { a chat. }\end{array}$ \\
\hline $\begin{array}{l}\text { 5. Creating a story } \\
\text { Time: } 2 \text { hours }\end{array}$ & $\begin{array}{l}\text { Writing compound } \\
\text { sentences. }\end{array}$ & $\begin{array}{l}\text { To sequence and create a new } \\
\text { version for a story. }\end{array}$ \\
\hline $\begin{array}{l}\text { 6. Creating my own poem } \\
\text { Time: } 2 \text { hours }\end{array}$ & $\begin{array}{l}\text { Linking ideas/ } \\
\text { connectors. }\end{array}$ & $\begin{array}{l}\text { To write poems based on figures and } \\
\text { colors through the forum. }\end{array}$ \\
\hline $\begin{array}{l}\text { 7. My favorite animal } \\
\text { Time: } 2 \text { hours }\end{array}$ & $\begin{array}{l}\text { Describing animals } \\
\text { using adjectives. }\end{array}$ & $\begin{array}{l}\text { To refer to students' favorite pets by } \\
\text { means of a forum. }\end{array}$ \\
\hline $\begin{array}{l}\text { 8. Composing a chorus } \\
\text { Time: } 2 \text { hours }\end{array}$ & $\begin{array}{l}\text { Past, present, and } \\
\text { future simple. }\end{array}$ & $\begin{array}{l}\text { To promote student interaction } \\
\text { through the forum in order to create } \\
\text { and share a chorus. }\end{array}$ \\
\hline $\begin{array}{l}\text { 9. Famous characters profiles } \\
\text { Time: } 2 \text { hours }\end{array}$ & Paragraph arrangement. & $\begin{array}{l}\text { To create and share a famous } \\
\text { person's profile using the wiki. }\end{array}$ \\
\hline $\begin{array}{l}\text { 10. A musical magazine } \\
\text { Time: } 2 \text { hours }\end{array}$ & $\begin{array}{l}\text { Paragraph arrangement, } \\
\text { punctuation. }\end{array}$ & $\begin{array}{l}\text { To collaboratively create a section of } \\
\text { a music magazine by means of a wiki. }\end{array}$ \\
\hline $\begin{array}{l}\text { 11. What do you think about...? } \\
\text { Time: } 2 \text { hours }\end{array}$ & $\begin{array}{l}\text { Writing a critical } \\
\text { composition. }\end{array}$ & $\begin{array}{l}\text { To follow different stages for the } \\
\text { creation of a critical composition. }\end{array}$ \\
\hline
\end{tabular}

The following section describes the instruments, techniques, and procedures to collect data and the ways they contributed to create the categories and answer the research inquiry. 


\section{Instruments, Techniques, and Procedures for Data Collection}

To gather information, we used the elicitation and observation techniques and some instruments such as interviews, students' artifacts, and journals. From interviews we got students' perceptions regarding virtual resources; students' artifacts revealed information related to their writing features at the moment of working in the virtual room and the extracts taken from journals provided data related to their behaviors and attitudes.

Elicitation technique. According to Gubrium and Holstein (2001), "elicitation uncovers an articulated informant knowledge" (p. 78). The instruments within this technique which were used to gather information were as follows:

Interview. Through this instrument we gathered some information, thoughts, and feelings of students in relation to their work in the virtual room. The interview was applied to some students who were selected at random at the end of the application of all the workshops. Therefore, students got the opportunity to refer to their perceptions regarding the way each workshop was applied as well as their motivation and learning goals by working in it.

Students' artifacts. This instrument was used in order to collect samples of students' writings in English (forums, chats, and wikis) and identify its features when working on the different virtual tasks. Students' samples were safe in the personal account of each one of them and those works were collected and analyzed when students finished each activity developed in the virtual room.

Journals. This instrument was used to report students' reactions and behaviors during their work in the virtual room. In the next section of the document we present the data analysis chapter which explains and shows the results of the research carried out and its categorization.

\section{Data Analysis}

The categorization was carried out by classifying and grouping the common patterns we identified in the data collected by means of interviews, students' artifacts, and journals using methodological triangulation. Data analysis was based on the grounded theory proposed by Strauss and Corbin (1997): "It is a qualitative method that uses a systematic set of procedures to develop an inductively derived grounded theory about a phenomenon" (p. 26). The main objective of grounded theory is to expand upon an explanation of a phenomenon by identifying the key elements in the context and process of the experiment.

Table 2 shows the research inquiry, the categories, and subcategories that emerged from the data analysis. 
Table 2. Categories and Subcategories

\begin{tabular}{|c|c|c|}
\hline Research Question & Categories & Subcategories \\
\hline \multirow{5}{*}{$\begin{array}{l}\text { To what extent does } \\
\text { the use of a virtual } \\
\text { room shape EFL } \\
\text { writing of students in } \\
\text { a public school? }\end{array}$} & $\begin{array}{l}\text { 1. Enriching Vocabulary to } \\
\text { Express Ideas }\end{array}$ & \\
\hline & \multirow{2}{*}{$\begin{array}{l}\text { 2. Engaging Students in } \\
\text { Writing }\end{array}$} & 2.1 Writing Texts Cooperatively \\
\hline & & 2.2 Interactive Writing \\
\hline & \multirow{2}{*}{$\begin{array}{l}\text { 3. Shaping Writing Skill } \\
\text { Through a Virtual Room }\end{array}$} & 3.1 Giving Some Sense to Writing \\
\hline & & $\begin{array}{l}\text { 3.2 From the Reproduction of Rules } \\
\text { to Communicative Texts }\end{array}$ \\
\hline
\end{tabular}

\section{Enriching Vocabulary to Express Ideas}

Language is a complex system which is composed of a series of elements that ensures its correct use and understanding (grammar rules, coherence, cohesion, vocabulary, among others). In relation to vocabulary, it is a necessary and important factor in order for learners to be able to express ideas, opinions, feelings, and thoughts more meaningfully.

We thought it was important to enrich the students' vocabulary for the purpose of enhancing their writing expression by constructing longer and significant texts. In the research proposal, we designed and used a variety of virtual activities and games where students had the opportunity to match pictures with abstract concepts, to participate in memory games, and to play with puzzles.

One of the tools used for collective writing was the wiki. It is an online workplace that allows members cooperatively to create and edit web pages. Richardson (2006) states the wiki is a "collaborative web space where anyone can add content and anyone can edit content that has already been published" (p. 8). In the research the collective writing activities students were assigned gave them the opportunity to take part in the creation of magazines and stories, among others, where each one had a specific function related to the writing of a subtopic or a part of the whole text. In the following sample taken from a wiki, students wrote cooperatively the Three Little Pigs story:

There once was a pig who built a straw house was so happy because I had a place of refuge but did not know that happiness would not last long. Days after a wolf came home and collapsed puff and blow all the little pig had built, the house of straw was now a total disaster. [sic] (Carlitos, Workshop 5, Students' Artifacts) 
The same aspect was also observed in the following sample:

In the first moment I saw you

It was love at first sight

With your eyes incandescent

And your eyes forecent. [sic]

(Panchita, Workshop 6, Students' Artifacts)

On the other hand, after the development of those activities students seemed to use a more diverse vocabulary according to the kind of text they were writing. They also could create more complete writings, as Juanita claimed in the interview.

T: What do you think about the use of virtual tools in the English class?

S: I think it is good, very good and fun.

T: Why?

S: Because I learned lots of things, besides, it helped me to learn vocabulary and verbs. There are many words that I did not know. Now I can use them in class to talk to my classmates and develop tests. ${ }^{1}$

In the sample above, the student established that she could use the language in order to write coherent texts thanks to the vocabulary and grammar use that the activities required. Moreover, she referred to the implications of knowing another language in her personal and academic life.

\section{Engaging Students in Writing}

Over the past few years the use of technology has been increasing in the teaching-learning process. Teachers have brought new strategies and techniques to the classes. They now have the opportunity to use useful resources to practice and develop different kinds of tasks. So, they provide students new learning approaches in a more meaningful and interesting manner and motivate them to learn while at the same time fostering their language skills.

For this reason, teachers should promote the implementation of virtual tools in the learning process. In this sense, virtual tools such as wiki, chat, and forum helped students to practice and foster their writing skill in a cooperative and interactive way. Students used the language to write about a specific topic and interact with their classmates by answering questions, giving opinions, and writing comments about the different writings they produced. In relation to this, Mandal (2009) stated: "Being independent and working in a team, gives a person an opportunity to share himself deeply, meaningfully with others and have access to

\footnotetext{
1 This sample has been translated from Spanish. T stands for teacher and S for student.
} 
the vast resources and potential of other human beings" (p. 189). Regarding this assertion, cooperative writing becomes a recursive task, where students can know and teach the others useful items when creating a paragraph or text cooperatively. Moreover, cooperative writing allowed students to develop their English writing skill more easily because cooperation helps them exchange ideas, feelings, and thoughts at the moment of creating their writings.

For instance, in Workshop 9 students wrote a text with the use of the wiki, which allowed them to know what their partners wrote and go on constructing the text. They had to add information to the writing taking into account the topic and the purpose of the activity. In this case, they had to construct a text about a famous person, Jennifer Lopez. She was selected by a small group of students; the others selected a different famous person.

Carlitos: Jennifer is an actress, singer, dancer, producer and designer of American fashion. [sic]

Pachito: She was born on July 24, 1969 and her real name is Jennifer Lynn Lopez. She is married with Marc Anthony. [sic]

Panchita: She is the most beautiful women; she sings good songs, she dance very well. And she has an excellent voice. [sic]

(Workshop 9, Students' Artifacts)

At the end of the workshops, we applied an interview in which students talked about the importance of the virtual tools use in the English writing skill. They mentioned the advantages of working with those materials when learning a language. We see this in Lolita's interviews.

T: Ok, What do you think about the use of virtual tools in the English class?

S: I think it is good, it is entertaining to work with technology to be updated.

T: Why do you think it is good?

S: Well, you feel more motivated when you work with virtual tools, I think that with all of those resources you can learn and practice many things.

T: What do you think about the way how texts' writing was carried out in class?

S: It was good, because we knew and learned many things which are important for our English learning in a creative and dynamic way.

T: How was your experience in class when working in the virtual room?

S: I can say that it was nice, I learned many things, I improved my writing and it motivates me to study English. ${ }^{2}$

2 Sample translated from Spanish. 
From this sample, we can deduce that students found a fun and creative space to learn English and complement the formal instruction they received in the classroom. According to the students' answers, the work in the virtual room was productive and got them motivated towards learning and developing their skills, specially, those concerning writing.

This was also evident in the following notes taken from journals:

There is a lot of noise in the classroom because the computers are not working; the students seem anxious and distracted. Now, after 15 minutes most of the computers have started to work out and the students start to make questions to the teachers about the way the workshop is going to be developed, then the teachers explain the activities, the students participate actively using the virtual room resources. Sometimes, they ask the teacher for help to solve doubts and get their work checked ... most of students have finished the workshop. Some of them review the exercises and activities they had done. (Journal 1) ${ }^{3}$

Writing texts cooperatively. "Being independent and working in a team gives a person an opportunity to share himself deeply, meaningfully with others and have access to the vast resources and potential of other human beings" (Mandal, 2009, p. 189). Regarding this assertion, cooperative writing becomes a recursive task, where students can know and teach the others useful items when cooperatively creating a paragraph or text. In the cooperative learning method when a teacher gives a writing task, the members of the groups work together to reach certain shared learning goals. In our case, we designed writing activities to be worked by groups. Each activity was focused on a specific purpose i.e. students had to create texts or paragraphs in a collaborative way; for instance, poems, stories, songs. It was easy for them to write because they supported each other.

In the research the cooperative writing activities completed gave students the opportunity to take part in the creation of magazines and stories, among others, where each one had a specific function related to the writing of a subtopic or a part of the whole text. In the following sample taken from a wiki, students wrote cooperatively the Three Little Pigs story.

The three little pigs: Once there were three little pigs who were poor, then went into town to find work and build their home. [sic] (Workshop 5, Students' Artifacts, wiki taken from Lolita's account)

The three little pigs: The big bad wolf blew and blew and his house collapsed then the two little pigs ran home from third pig as the buy brick to create your home. shortly after the big bad wolf came and blew and puff but could not bring down the house making angry and blows air but cannot because the purpose of it is to eat the three little pigs. [sic] (Workshop 5, Students' Artifacts, wiki taken from Panchita's account)

3 Sample translated from Spanish. 
In these samples, students wrote a short story about the three little pigs. They were organized in a specific group just as the rest of the students. Thus, they were asked to write a particular part of the story taking into account the previous one. For instance, in the sample Lolita wrote the beginning of the story and based on that, Juanita could write the next part of the story. Finally, Panchita wrote the final part of the story according to her partners' ideas.

Interactive writing. Writing is a complex process that requires time, responsibility, and commitment. It demands that writers reflect on what they want to write, how to do it and to have knowledge about the topic they are going to talk about in order to create interesting and comprehensible writing tasks. Through the use of the forum students could write opinions about their classmates' creations. Each student had the opportunity to read the others' comments and reflections about their texts. In this way, students found another space to write interactively, which means, they had to create coherent answers about what was said before; they could also learn new written conversational clues in the virtual interaction with other people. A sample of what is said above is illustrated in Figure 1, a sample of a forum taken from Lolita's account.

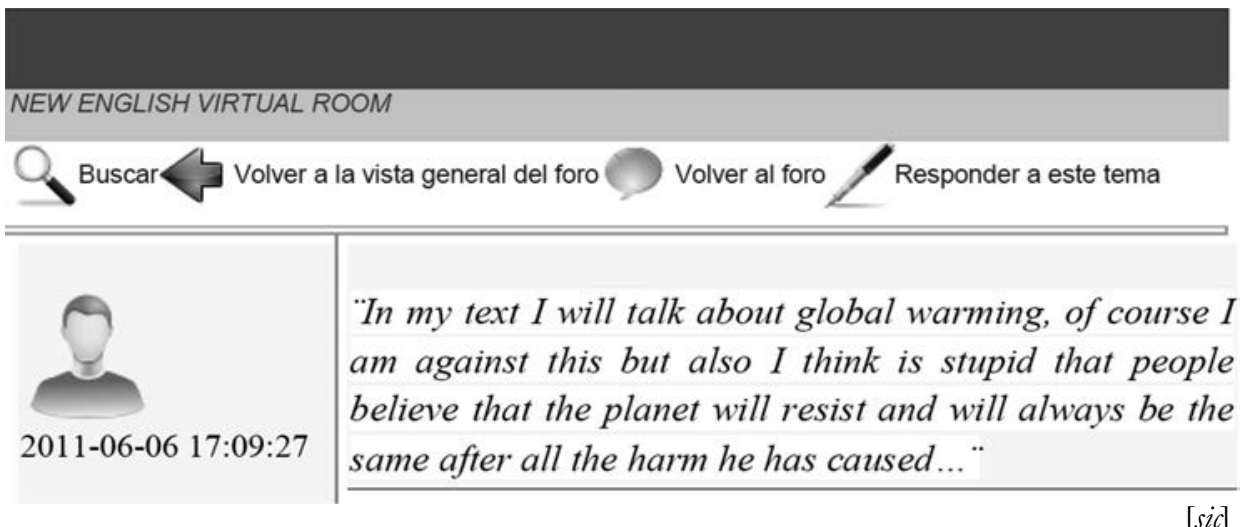

Figure 1. Sample, Workshop 11, Students’ Artifacts

Figure 2 shows a sample taken from Juanita's account. It belongs to Workshop 6 and the virtual tool used was the forum. 


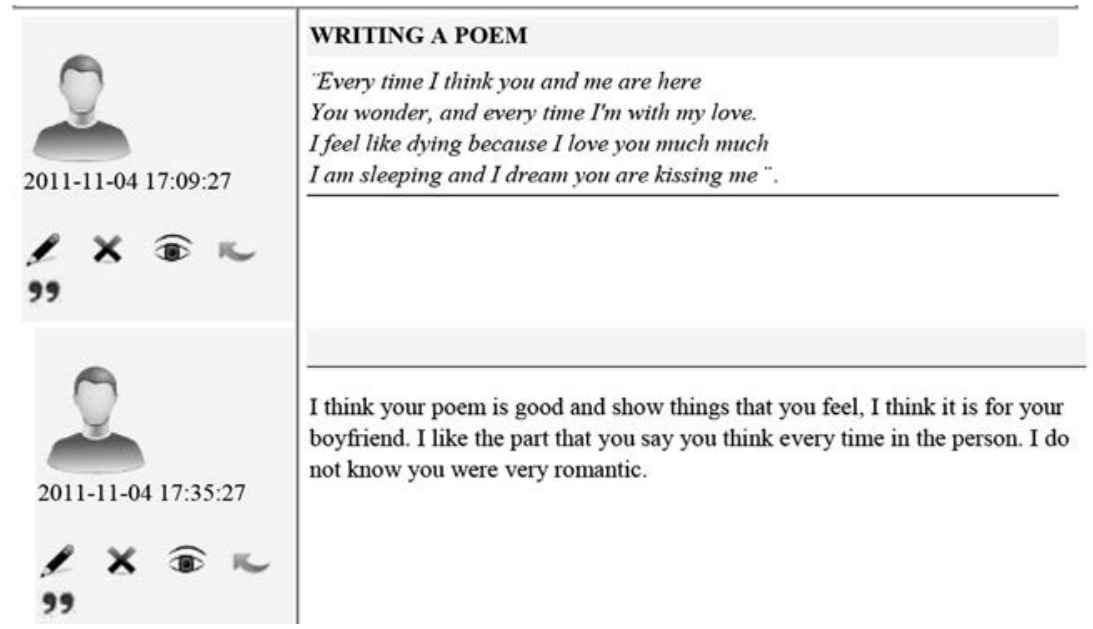

Figure 2. Sample, Workshop 6, Students' Artifacts

\section{Shaping Writing Skill Through a Virtual Room}

Technology opens a wide range of opportunities for people to learn and have contact with diverse resources. A virtual room is one of such resources, which allows linking web pages, videos, games, Microsoft Office documents, and creating your own learning site to place different kinds of exercises according to personal and academic needs. That is why a virtual room constitutes an option that teachers should incorporate in their teaching-learning process: to reinforce the topics worked in class and practice the students' skills in a more attractive way.

In the activities designed through the virtual tools used (wiki, chat, and forum) students developed different exercises, where they found videos, games, and useful links to be used in order to practice their writing skill. They had the chance to write phrases, give opinions about specific topics and their classmates' productions, and develop some exercises focused on feelings and opinions. These were the ways that students could start to make some sense about what they were writing and set whole ideas to a series of matching sentences. They learned that they could not communicate with only few sentences but structured paragraphs that made their expression clearer and meaningful.

For instance, in a forum which was about the creation of a chorus for a song, Panchita wrote what is shown in Figure 3. 


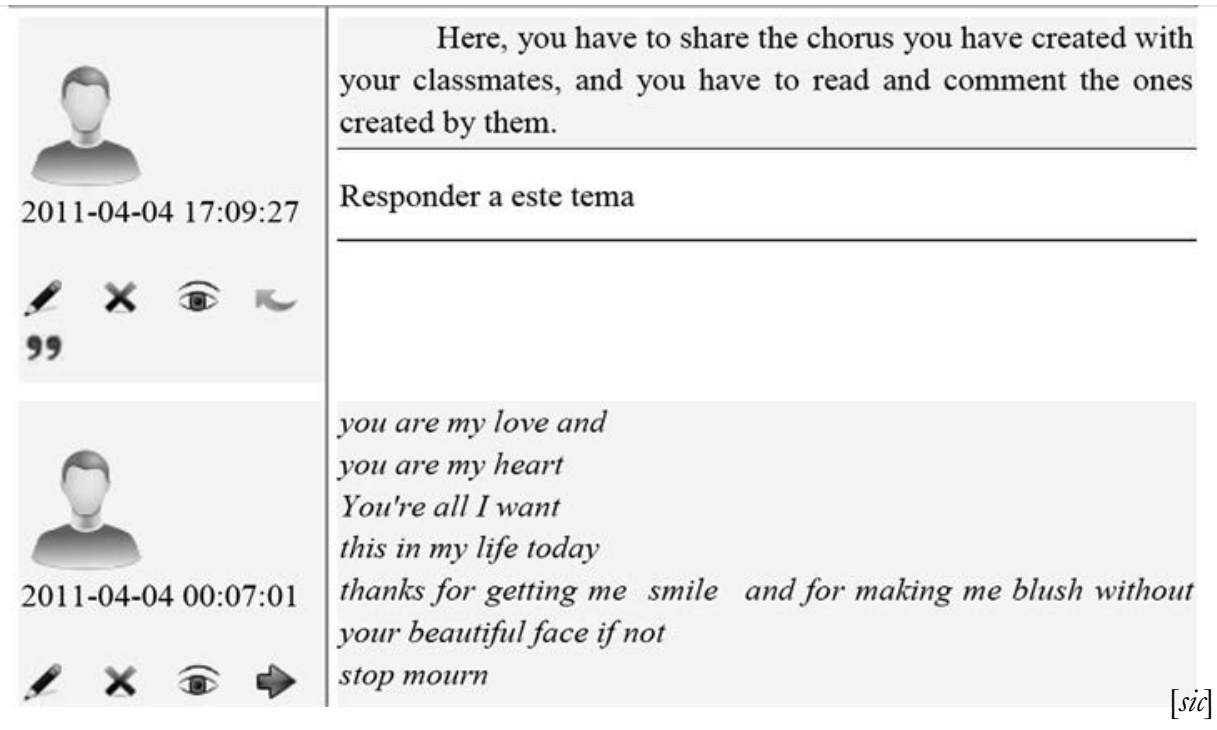

Figure 3. Sample, Workshop 8, Students' Artifacts

Another example of the creation of paragraph and sentence matching in order to communicate ideas is evident below. It is a sample of a wiki taken from Pepito's account:

Jennifer Lynn Lopez, she is from Bronx, New York, she is a good singer and dancer, she is an actress. She is married with Marck Antonie. She sing very good, she compouse beautiful songs and she sings in English and Spanish. She is pretty and young. She has five boyfriends and two beautiful sons.

Jennifer is the richest person of Latins America. She is a happy woman and she likes dance, sings and act. Her favorite sport is tennis, and her favorite hobby is travel. She likes eat fruits and vegtables. [sic] (Workshop 9, Students' artifacts)

For the creation of the last profile, students were divided into groups and each one assumed a specific role and task. For instance, one student was responsible for searching for information about personal facts and other students searched for information about professional aspects. Finally, they joined the information found and created a whole text based on all the students' ideas.

From these examples we can see that students started to write joined ideas using some connectors and giving coherence in relation to the content of the ideas. The students were able to create paragraphs based on their own feelings, which showed the language as 
a means for them to communicate through complete ideas that make sense for them and the readers.

Giving some sense to writing. Cohesion and coherence are aspects that give texts some sense in order for them to be understood by people who read them. Without those elements it is difficult to put ideas into words and communicate complete meanings. Regarding cohesion we have connectors of content similitude, which make texts whole nets composed of sentences linked among them. In relation to coherence, it refers to the property of the ideas being similar in content, pointing out the general meaning of the complete text. According to Kies (1995): "Coherence is [a] product of many different factors, which combine to make every paragraph, every sentence, and every phrase contribute to the meaning of the whole piece" (p. 123).

When starting to write texts in a language, especially in an unknown one, learners feel as if they are writing isolated sentences or words and mixing ideas within an only text, which results in writings that are lists of items about different topics without connection and that are difficult to understand by readers. In this regard, Kies (1995) states that coherence in writing is much more difficult to sustain than coherent speech simply because writers have no nonverbal clues to inform them as to whether their message is clear or not. To avoid this fact, teachers should create different strategies in order for students to learn to write complete ideas that are focused on a single sense.

The activities pointed out the function of the language components rather than only their form, so that when students could observe a grammatical aspect applied in context they were able to use it later in a similar way, by means of association in order to express their own ideas, thoughts, and experiences. In the following section of a chat, in which students had to refer to their last vacations, we can see that the two students used coherence and cohesion elements in order for them to be understood by their classmates:

Juanita: On my vacation I went to Bogota and I met friends I have not seen for a long time. Also, I watched television because I like but there I was little bored. [sic]

Carlitos: Wonderful, on my last vacation I went to Cartagena with my parents, I was on the beach and swan much then I knew a girl pretty. After I bougth things wonderful. [sic]

(Workshop 1, Students' Artifacts)

In the previous samples, it is evident that students wrote with a communicative purpose and joined ideas to shape whole meanings. Coherence and cohesion are also evident in the students' written creations shown in Figure 4. These samples were taken from the forum in Panchita's and Carlitos' account and show a more complex use of English grammar aspects. In this opportunity, students gave coherence and cohesion to their writings by keeping a whole topic of discussion along the text, using connectors to 


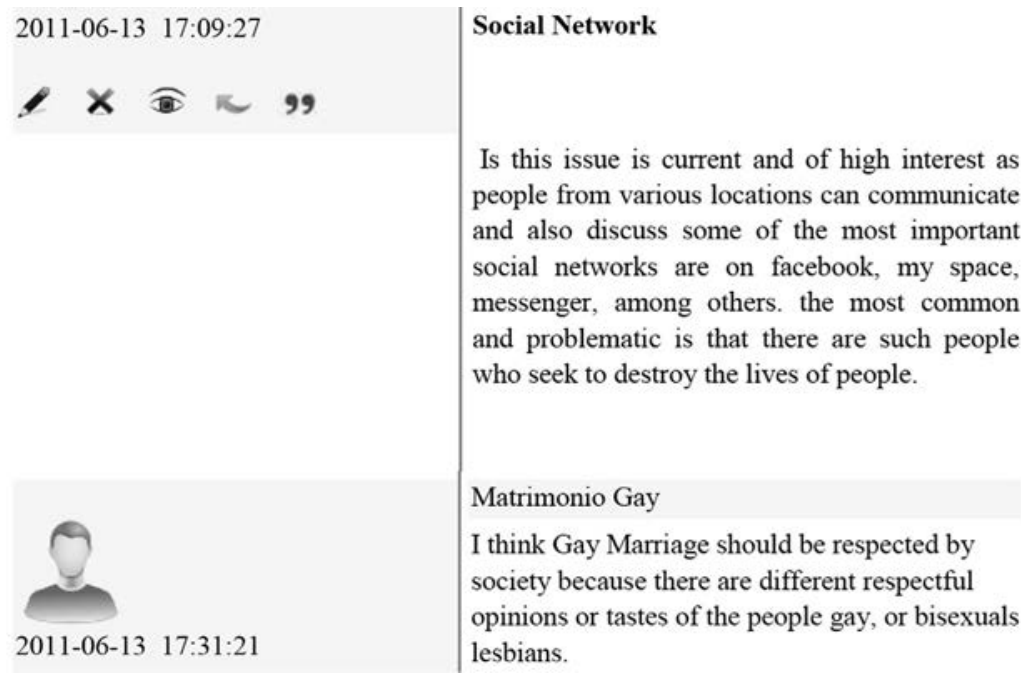

Figure 4. Sample, Workshop 11, Students' Artifacts

explain or add information to their opinions as well as resorting to a specific verbal tense to refer to different ideas.

From the reproduction of rules to communicative texts. In the moment of writing, students sometimes bear in mind the structure of the sentences leaving aside the content of their compositions. In fact, they are worried about the correct use of grammar rules more than in the function of them. For this reason, they are not aware of what they write; some of them only do it because they want to get a high grade for the class, forgetting the goals of communicative writing.

When students write with communicative purposes, they perceive this activity not as a duty but as a pleasure. Thus, they give more sense to the texts and feel more motivated because they know their creations are going to be read by other people and these are not going to be stored only in their notebooks. Likewise, they can read other compositions of their classmates which let them know their personal opinions and even themselves while they are learning.

This communicative approach in students' writing is showed in Figure 5, which is a sample taken from a poem written by Lolita. In this opportunity, students interacted by means of a forum. 


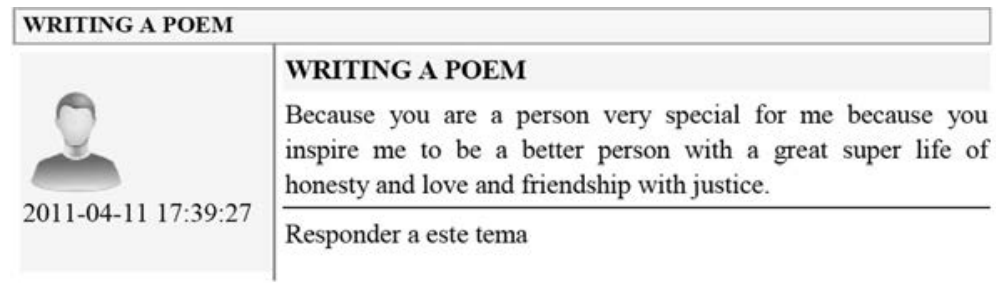

Figure 5. Sample, Workshop 6, Students' artifacts

The next sample was taken from a chat on likes and dislikes; here students interacted among themselves to show their preferences in relation to food, sports and hobbies, and to give opinions about their classmates' likes and dislikes.

[14/03/11 22:01:28]Panchita: Pachito, do you like pizza, i like to eat pizza very much.

[14/03/11 22:01:39]Pachito: no, I do not like pizza, I eat snaks, are more delicious. Pizza is ugly. And you

[14/03/11 22:01:41]Pepito: $q$ nada [nothing]

[14/03/11 22:01:44]Juanita: who choose not?

[14/03/11 22:01:47]Lolita: hello Pachito, how are you? You know I like to eat much, I like to eat pizza, snacks and meat.

[14/03/11 22:01:54]Panchita: who is hear...I dislike chees, but I like to eat apples, my mother gives apples all days. [sic] (Workshop 4, Students' Artifacts)

By interacting in this chat, students were able to follow a short virtual conversation, where they talked about what was to them a familiar topic. They shared some aspects of their lives with other classmates and used the language they knew to share their likes and dislikes with their classmates. In spite of their having made some grammar mistakes, they were concerned in their interaction with the others and it engaged them to write in order to refer to some aspects and establish a coherent conversation.

\section{Conclusions}

The use of virtual tools promoted a pleasant work atmosphere in the classroom and encouraged students to write different types of texts based on logical sequences of activities and online exercises. Throughout the development of the pedagogical proposal we could detect an increase in students' motivation and awareness in relation to their own language learning when they were writing, since they learned how to use the language in contexts and 
give a purpose to their writings. They started to see their texts as printed ways to communicate with their classmates and teachers and express feelings, opinions, and needs.

The results of the study show that a virtual room and resources within it can help learners to know about a wide range of vocabulary by means of games, online readings, videos, and interactive activities and avoid acquiring vocabulary to become a rote process. In the first activities, students still showed a lack of vocabulary, but as the project went on, students began to use more varied words, discriminated among the kind of vocabulary to use according to the type of text they were writing, and linked their ideas with connectors.

Cooperative writing by means of wikis fostered self and co evaluation: Students could teach and learn from the others and their own mistakes in relation to the language use when writing. Feedback took place when students had to carry out group activities in which they corrected their classmates to get more coherent and cohesive texts and achieve the goals of the given exercises; these were not only assessed but also shared with the whole class.

Interactive writing by means of a forum was also an important aspect to enhance writing skills. Students posted comments about the others' texts and opinions, building up personal and collective meanings so they were given a purpose to write not only to get a mark but mainly to be heard by a real audience. They cared more about improving their texts and understanding their classmates' postings by looking up unknown words and reviewing verbal tenses.

In the final products that students submitted (poems, wikis, stories, etc.), they used content and formal aspects such as coherence and cohesion plus they learned how to join ideas in whole and logical meanings. These aspects made their texts more comprehensible and significant to the readers and let learners go beyond the reproduction of rules and isolated sentences that they used to write as a way to represent how a specific verbal tense is made up.

Chats opened up a wide space of interaction and authentic communication where learners talked about familiar topics and daily life experiences. They wrote faster and more spontaneously with intrinsic goals, leaving aside external demands such as teachers' remarks and grades and, additionally, they felt free to ask questions of their classmates and get to know about each other using the language they had learned before. Teachers also participated in the chat rooms; some students talked to them, which increased the level of confidence and empathy among them.

\section{Pedagogical Implications}

Virtual resources open up a wide variety of opportunities for students to learn through resources such as videos, songs, games, forums, and so forth. These are connected to their immediate needs, feelings, and interests. By using them in the classroom students can find creative ways to comprehend abstract contents easier and faster. 
The use of technology within the classroom lets students play a more active role where they are aware of their own learning and are more autonomous in relation to their practices as learners. Technology leads them to create, analyze, research, and communicate contents, where they learn by experiencing and doing in different contexts.

There is a need for more research on the role of a virtual room to enhance the writing skill as a process. Tools such as wikis, forums chats, and online resources can help students to go through different stages when writing texts (brainstorming, prewriting, drafting, revising, and editing), supported by teachers and other learners. Thus, students can follow a whole process where they manage their own learning being aware of the ideas they are writing about and the language they need.

Further research should go beyond e-learning to get into a new concept in teaching: "blended learning" (combining online with face-to-face interaction), which has grown in the last few years. In this study, it was evident that some students wrote rough drafts before submitting their texts in the virtual room and asked for revision out of the platform, so with the integration of physical and virtual environments, students were able to get more meaningful feedback and have access to more varied input and resources to improve their writing skill and their language use itself.

A final issue to be considered concerning the use of virtual resources in EFL is the method(s) to assess students' performance. Teachers should test not only the products students create but also the process they follow to achieve the goals of the online exercises; some students evidence more devotion and concern about their learning by exploring the materials and activities they are given and looking for additional resources to enrich their experience, while others just pay attention to the activities to be graded, which is not always evident in the texts they write.

\section{References}

Bruffee, K. A. (1986). Social construction, language, and the authority of knowledge: A bibliographical essay. College English, 48(8), 773-790.

Byrne, D. (1988). Teaching writing skills. Harlow, UK: Longman.

Calhoun, E. F. (1994). How to use action research in the self-renewing school. Alexandria, VA: Association for Supervision and Curriculum Development.

Dougiamas, M. (1998). An exploration of the use of open source software to support a social constructionist epistemology of teaching and learning within Internet-based communities of reflective inquiry (Doctoral dissertation). Curtin University of Technology, Perth, Australia.

Gubrium, J. F., \& Holstein, J. A. (2001). Handbook of interview research. London, UK: Sage.

Hiltz, S. R. (1987). The virtual classroom: Learning without limits via computer networks. Norwood, NJ: Ablex Publishing. 
Kies, D. (1995). Coherence in writing: The Hyper Text Books. Retrieved from http://papyr.com/ hypertextbooks/comp1/coherent.htm

Klopfer, E., Osterweil, S., Groff, J., \& Haas, J. (2009). Using technology of today, in the classroom today: The instructional power of digital games, social networking, simulations and how teachers can leverage them. Cambridge, MA: Massachusetts Institute of Technology. Retrieved from http:// education.mit.edu/papers/GamesSimsSocNets_EdArcade.pdf

Mandal, R. R. (2009). Cooperative learning strategies to enhance writing skill. The Modern Journal of Applied Linguistics, 1(2), 95-102.

Papert, S., \& Harel, I. (1991). Constructionism. Norwood, NJ: Ablex Publishing.

Parsons, R., \& Brown, K. (2002). Teacher as reflective practitioner and action researcher. Belmont, CA: Wadsworth/Thomson Learning.

Pfister, H., Schuckmann, C., Beck-Wilson, J., \& Wessner, M. (1998). The metaphor of virtual rooms in the cooperative learning environment CLear. In N. Streitz, S. Konomi, \& H. Burkhardt (Eds.), Cooperative buildings: Integrating information, organization and architecture (pp. 107-113). Berlin, GE: Springer.

Richardson, W. (2006). Blogs, wikis, podcasts, and other powerful web tools for classrooms. Thousand Oaks, CA: Corwin Press.

Rojas, G. (2011). Writing using blogs: A way to engage Colombian adolescents in meaningful communication. PROFILE Issues in Teachers' Professional Development, 13(2), 11-27.

Sandin, M. P. (2003). Investigación cualitativa en educación: fundamentos y tradiciones [Qualitative research in education: Fundamentals and traditions]. Barcelona, ES: Mc Graw Hill.

Scott, V. M. (1996). Rethinking foreign language writing. Boston, MA: Heinle \& Heinle Publishers.

Strauss, A. C., \& Corbin, J. M. (1997). Grounded theory in practice. London, UK: Sage.

Tiffin, J., \& Rajasingham, L. (1995). En busca de la clase virtual: la educación en la sociedad de la información [In search of the virtual class: Education in the information society]. Barcelona, ES: Ediciones Paidós.

Wassman, R., \& Rinsky, A. (1997). Effective reading in a changing world. State College, PA: Prentice Hall.

Williams, M., \& Burden, R. L. (1997). Psychology for language teachers: A social constructivist approach. Cambridge, UK: Cambridge University Press.

\section{The Authors}

Dayra Piedad Ochoa Alpala holds a B.A. in modern languages from Universidad Pedagógica y Tecnológica de Colombia. She currently teaches English as a foreign language at Universidad de Boyacá in Tunja (Colombia). She has taught primary and high school students in different institutions in Boyacá.

Nieves Medina Peña is a teacher of modern languages from Universidad Pedagógica y Tecnológica de Colombia. Her professional experience has been as both English and Spanish teacher in primary and secondary levels. She is currently working as a member of the bilingualism project carried out by the Secretary of Education. 